\title{
Plasma antibodies that cross react to subtype- $B$ and $C$ third variable (V3) region develop in Indian HIV-1 infected ilndividuals with time
}

\author{
R Andrabi ${ }^{1}$, A Gupta $^{1 *}$, M Bala $^{2}$, K Luthra $^{1}$ \\ From AIDS Vaccine 2012 \\ Boston, MA, USA. 9-12 September 2012
}

\section{Background}

Subtype-C alone accounts for approximately $50 \%$ of global and more than $95 \%$ human immunodeficiency virus1(HIV-1) infection in India. Identification of antigenic epitopes that induce antibodies with cross-clade activity will be crucial to address the HIV-1viral diversity.

\section{Methods}

80 HIV-1 infected drug naive patients were recruited for this study. The study was approved by the institute ethics committee and informed consent was obtained from all the participants. The relative binding of anti- $\mathrm{V} 3$ polyclonal plasma antibodies to 35 mer consensus $\neg-B$ and C V3 peptides was done by ELISA binding assay. Statistical analysis was performed by Graphpad Prism 5 .

\section{Results}

Assessment of the relative binding revealed that 86\% (69/ 80) of the plasma were able to reach an IC50 binding titer with consensus-B V3 peptide with substantially low antibody titers compared to binding with consensus- $\mathrm{C}$ V3 (mean IC50 V3-C $=12611$ versus V3-B=2736) $(\mathrm{p}<0.0001)$, implying that although majority of the antibodies were subtype specific, a good proportion of cross reactive antiV3 antibodies also exist in these plasma (range $=1-97 \%$, mean $=23 \%$ ). We observed a strong correlation between percent cross reactive anti-V3 antibodies and days from first diagnosis $(\mathrm{n}=80$ : $\mathrm{r}=0.29 \mathrm{p}=0.008)$ while no such association was found with other clinical and immunological parameters like plasma viral load $(\mathrm{n}=53: \mathrm{r}=0.16 \mathrm{p}=0.24)$, CD4 count $(n=80: r=0.10 p=0.34)$, total plasma IgG levels

${ }^{1}$ All India Institute of Medical Sciences (AlIMS), New Delhi, India

Full list of author information is available at the end of the article $(\mathrm{n}=65: \mathrm{r}=-0.09 \mathrm{p}=0.45)$ and eventually with the V3 sequence of donor viruses.

\section{Conclusion}

This is the first study to demonstrate the presence of cross-clade reactive anti-V3 antibodies and their association with time in the plasma of HIV-1 infected Asian Indians from north India.

\section{Author details}

${ }^{1}$ All India Institute of Medical Sciences (AIIMS), New Delhi, India. ${ }^{2}$ Regional STD Teaching Training and Research Centre,Safdarjung Hospital, New Delhi, India.

Published: 13 September 2012

doi:10.1186/1742-4690-9-S2-P55

Cite this article as: Andrabi et al:: Plasma antibodies that cross react to subtype-B and C third variable (V3) region develop in Indian HIV-1 infected ilndividuals with time. Retrovirology 2012 9(Suppl 2):P55.

Submit your next manuscript to BioMed Central and take full advantage of:

- Convenient online submission

- Thorough peer review

- No space constraints or color figure charges

- Immediate publication on acceptance

- Inclusion in PubMed, CAS, Scopus and Google Scholar

- Research which is freely available for redistribution

Submit your manuscript at www.biomedcentral.com/submit C Biomed Central 